\title{
Effects of weld size on stress concentration factors of CHS-CFSHS joints
}

\author{
Delei Yang \\ Department of Architectural and Civil Engineering, University of Huanghuai, Zhumadian 463000, China \\ Department of Civil Engineering, University of Ottawa, East Ottawa, ON K1N 6N5, Canada \\ dyang2@uottawa.ca
}

Lewei Tong

Department of Building Engineering, Tongii University, Shanghai 200092, China

tonglw@tongji.edu.cn

\begin{abstract}
This paper aims to disclose the effects of weld size on hot spot stress in the calculation of fatigue performance of the joints. For this purpose, the author explored the hot spot stress of CHS-CFSHS T-joints, which consists of circular hollow section (CHS) braces and concrete-filled square hollow section (CFSHS) chords. After reviewing the previous studies and the relevant specifications on weld size, the author probes into the effects of weld size on the stress concentration factor (SCF) of CHS-CFSHS joints via finiteelement analysis. The analysis show that the weld size directly affected the hot spot stress in both conditions, and the influence laws were largely the same; with the increase of weld size, the brace-side SCF plunged when the chordsize weld size remained the same, but the chord-side SCF changed slightly when the brace-side weld size was constant; the brace-side and chord-side SCF declined when the brace-side and chord-side weld sizes increased by the same amount. This research successfully determined the weld sizes that are consistent with the relevant specifications, and safe and simple to apply in actual engineering.
\end{abstract}

KEYWORDS. Weld size; Stress concentration factors (SCF); Finite-element analysis; Circular hollow section (CHS); Concrete-filled square hollow section (CFSHS); Welded joints.

\section{OPEN ACCESS}

Citation: Yang, D., Tong, L., Effects of weld size on stress concentration factors of CHSCFSHS joints, Frattura ed Integrità Strutturale, 45 (2018) 45-52.

Received: 07.05 .2018

Accepted: 29.05.2018

Published: 01.07.2018

Copyright: (C) 2018 This is an open access article under the terms of the CC-BY 4.0, which permits unrestricted use, distribution, and reproduction in any medium, provided the original author and source are credited.

\section{INTRODUCTION}

he concrete-filled steel tube (CFST) is a composite member consisting of a steel tube infilled with concrete. With high bearing capacity, good seismic property, strong fire resistance and short construction period, this new structure can satisfy the various needs of modern engineering structures, such as large-span, high altitude, 
overloading and industrialized construction $[1,2]$. As a result, the CFST has been extensively applied to build complex structures like industrial plants, high-rise buildings and large-span bridges.

The superiority of the CFST is partially attributable to its welded joints. Compared to other types of joints, the CFST's welded joints have a simple and neat appearance, with no protruding node, a clear force transmission line, a simple and easy-to-maintain structure. The static strength, stiffness, seismic property and fatigue performance of the welded joints are critical to the overall state of the CFST. For instance, the fatigue performance of the joints directly bears on the structural safety of bridges and offshore platforms, which are subjected to long-term alternating loads, and the service life of highrises and other structures under long-term wind loads.

Over the years, various methods have been developed to evaluate the fatigue performance of steel tube joints. Among them, hot spot stress stands out as the most popular and successful strategy for fatigue calculated of welded tube joints [315]. Nevertheless, there is not yet a consensus on the effects of weld size on hot spot stress in the calculation of fatigue performance of the joints.

To solve the problem, this paper explores the hot spot stress of CHS-CFSHS T-joints, which consists of circular hollow section (CHS) braces and concrete-filled square hollow section (CFSHS) chords. The T-joint is commonly used in engineering practice. It is the building block of complex 2D and 3D joints. After reviewing the previous studies and the relevant specifications on weld size, the author probes into the effects of weld size on the stress concentration factors (SCF) of CHS-CFSHS joints via finite-element analysis.

\section{LITERATURE REVIEW}

S o far, there is no agreement on the impacts of weld size on the SCF of welded joints. Some hold that the extrapolated SCF is not affected by weld size, because the extrapolation region is far enough from the weld toe. This view is reflected in the SCF formula for pure CHS joints in Reference [6], which does not consider the impact of weld size. Some believe that the weld size has a certain effect on the SCF of the welded joint, as evidenced by the SCF formula in Reference [3]. Below are two representative studies concerning the effect of weld size on the SCF of welded joints.

Wingerde conducted a finite-element modeling of fillet weld and full penetration butt weld of different sizes, aiming to disclose the effects of weld size on the SCF of SHS joints (Fig. 1). The modeling reveals that the brace-side SCF of fillet weld was 1.4 times that of the butt weld, while the chord-side SCF of the two types of weld was almost the same.

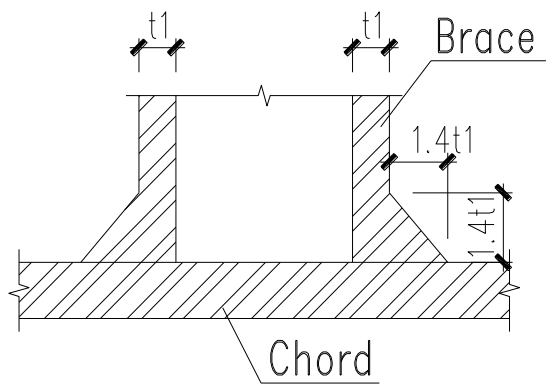

(a) Fillet weld

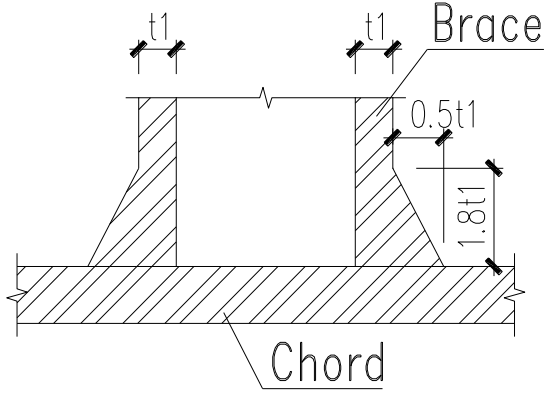

(b) Full penetration weld

Figure 1: Finite-element model of Wingerde.

Through finite-element analysis, Zheng Hongzhi examined the SCF of CHS-SHS joints under the different sizes of fillet weld, partial penetration butt weld, and full penetration butt weld [16]. To obtain the brace-side SCF of the joints with full or partial penetration weld, the weld size-brace wall thickness ratio was taken as a dimensionless factor in the finiteelement model, while brace-side weld size was maintained equal to the chord-side weld and subjected to four changes on four levels (Fig. 2(a)). To acquire the chord-side SCF of the joints with full or partial penetration weld, the weld size was set to the same level as that in the model of Wingerde for full penetration butt weld (Fig. 1(b)). The SCF of the joints with fillet weld was computed by the finite-element model in Fig. 2(b), where both brace-side and chord-side sizes of the fillet weld were 1.2tl. The theoretical SCFs obtained by Zheng were the upper limits of the corresponding joint. Nevertheless, the weld size-brace wall thickness ratio must be considered before computing the brace-side SCF of the joints with full or partial penetration weld. This complicates the computing process and adds to the difficulty of engineering application. 


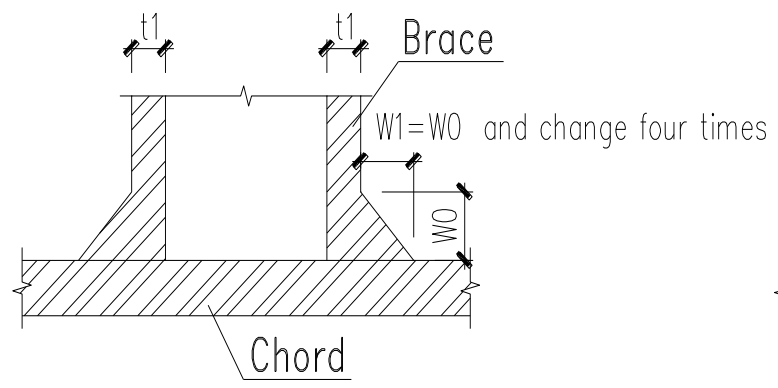

(a)

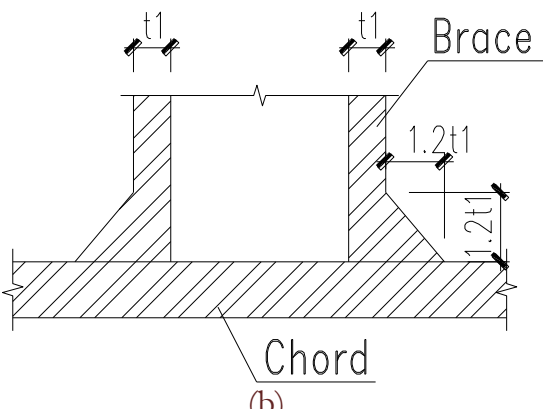

(b)

Figure 2: Finite-element model of Zheng Hongzhi.

\section{RELEVANT SPECIFICATIONS}

1 he current calculation method for hot spot stress adopts the minimum distance between the extrapolation region and the weld toe, seeking to eliminate the impact of the local shape of the weld. Mechanically speaking, the weld size has a positive correlation with the distance between the extrapolation region and the intersection area, the most obvious variation place of stiffness. In other words, the SCF tends to decline with the increase in the weld size. Hence, it is assumed here that the weld size does have an impact on the SCF. The range of weld size must be determined before studying the effect of weld size on the SCF of welded joints. Below is a review of the relevant specifications on weld size.

(1) For welded joints directly under fatigue load, the Technical Specification for Structures with Steel Hollow Sections (CECS 280:2010) [17] stipulates that the partial or full penetration weld should be adopted if the brace wall thickness $t$ is greater than $8 \mathrm{~mm}$; the fillet weld can be used if the brace wall thickness is smaller than or equal to $8 \mathrm{~mm}$ (Article 8.28).

(2) For tubular T-joints with full penetration weld, the Technical Specification for Welding of Steel Structure of Building (JGJ 81-2002) [18] stipulates that the minimum weld size should be $w 0=0.5 \mathrm{t} 1$ at the chord-side and $w 1=6 \mathrm{~mm}+0.767 \mathrm{t} 1 \mathrm{at}$ the brace-side (Article 4.3.6-1), where $\mathrm{t} 1$ is the brace wall thickness. That is, the minimum weld size-brace wall thickness ratio remains at 0.5 at the chord-size, and changes at the brace-side with brace wall thicknesses. Moreover, the ratio of weld-size to brace wall thickness should fall in 1.14 2.27 if the brace wall thickness varies between $4 \mathrm{~mm}$ and $16 \mathrm{~mm}$ (the brace wall thickness should not exceed $16 \mathrm{~mm}$ ) (Article 4.3.6-1).

(3) For tubular T-joints with fillet weld, the Technical Specification for Structures with Steel Hollow Sections (CECS 280:2010)[17] stipulates that the weld thickness should not be smaller than brace wall thickness t1 (Article 8.2.8) and should not exceed twice the brace wall thickness (Article 7.1.1-4); the Code for Design of Steel Structures (GB 500172013)[19] stipulates that the ratio of brace-side weld size to chord-side weld size can be 1: 1 (Article 8.2.8). In the rightangle fillet weld, the fillet weld size should be about 1.4 times of the weld thickness. In other words, the fillet weld size should not be smaller than $1.4 \mathrm{t} 1$, should not be greater than $2 \mathrm{t} 1$, and must not be greater than $2.8 \mathrm{t} 1$, where $\mathrm{t} 1$ is the brace wall thickness.

(4) For tubular T-joints with partial penetration weld, the Technical Specification for Structures with Steel Hollow Sections (CECS 280:2010) [17] stipulates that the fatigue performance of the weld should be the same as that of fillet weld, that is, the weld size should not be smaller than $0.5 \mathrm{t} 1$ at the chord-side or smaller than $1.73 \mathrm{t} 1$ at the brace-side, where $\mathrm{t} 1$ is the brace wall thickness.

\section{FINITE-ELEMENT ANALYSIS}

\section{Finite-element model}

TT eld configuration. Fig. 3 presents the three possible welds for the brace and chord of welded tube joints, namely, full penetration weld, partial penetration weld and fillet weld. Wingerde examined the weld configuration by finite-element method, suggesting that the effect of different weld configurations on the SCF is negligible [3]. Zheng Hongzhi also applied finite-element method to examine the impacts of different weld configurations on the SCF and concluded that the SCF of full penetration weld is less than $10 \%$ greater than that of the other two configurations under the same weld size and dimensionless parameters [16]. For reliability and accuracy, the three types of welds are all modeled according to the configuration of full penetration weld in this research (Fig. 3(a)). 


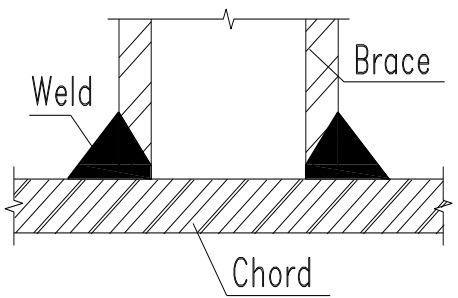

(a) full penetration weld

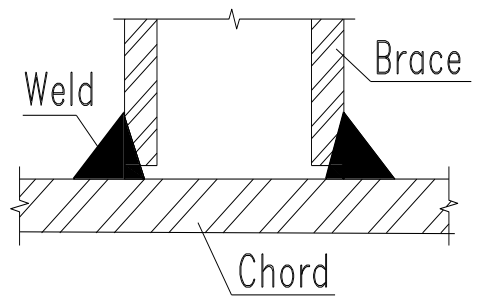

(b) partial penetration weld

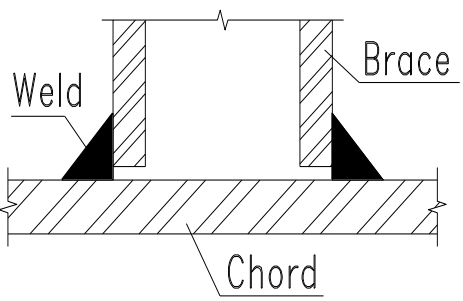

(c) fillet weld

Figure 3: Weld configuration

Calculation parameters and working condition. A total of six finite-element models (WT1 WT6) were established with $\mathrm{b} 0=200, \mathrm{~d} 1=80, \mathrm{t} 0=10, \mathrm{t} 1=5, \beta=0.4,2 \gamma=20$ and $\tau=0.5$, according to the relevant specifications on weld size of tube joints and the empirical range of influencing parameters of steel tubular joints $\beta=\mathrm{d} 1 / \mathrm{b} 0,2 \gamma=\mathrm{b} 0 / \mathrm{t} 0$ and $\tau=\mathrm{t} 1 / \mathrm{t} 0$. In WT1 and WT2, w0/t1 was set to 0.5 and $\mathrm{w} 1 / \mathrm{t} 1$ was set to $1.2 \sim 2.0$; In WT3 and WT4, w0 $={ }_{\mathrm{w}} 1$, and $\mathrm{w} 1 / \mathrm{t} 1$ was set to $1.2 \sim 1.8$; In WT5 and WT6, w1/t1 was set to 1.8 and w0/t1 was set to $0.5 \sim 1.0$. Fig. 4 and Fig. 5 respectively explain the meanings of $\beta, 2 \gamma$ and $\tau$, and the calculated SCF positions, where w0 is the chord-side weld size and w1 was the brace-side weld size.

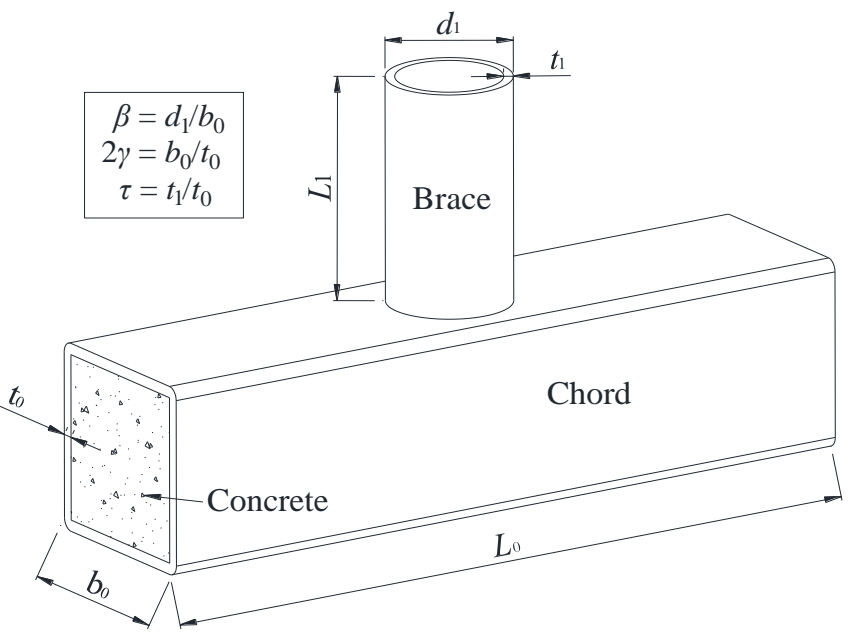

Figure 4: Schematic diagram of CHS-CFSHS T-joint.

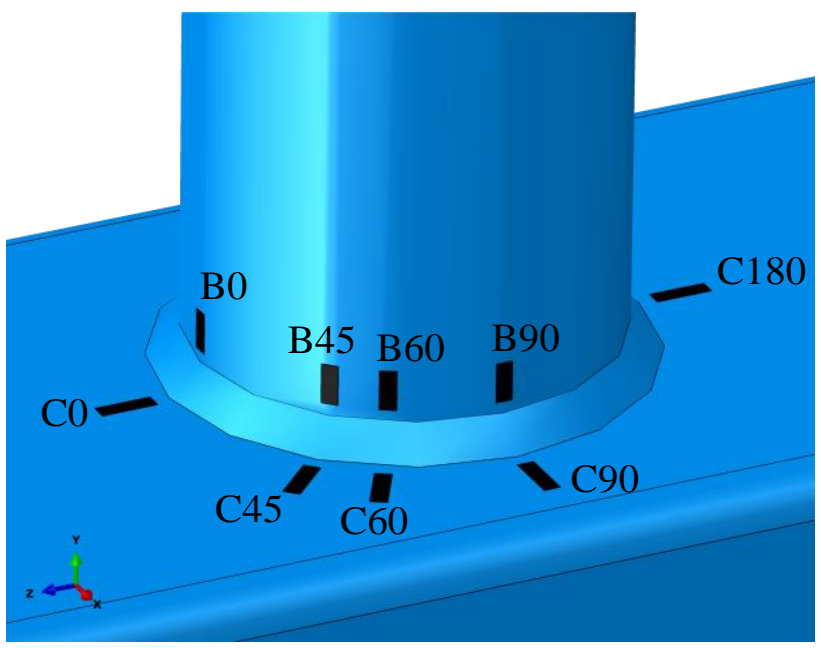

Figure 5: Calculated SCF positions

Given the symmetry of joints, a half finite-element model was constructed on the finite-element software Abaqus [20]. The steel tube was meshed into incompatible mode eight-node brick elements (C3D8I) and the concrete into eight-node brick elements with reduced integration (C3D8R). The face-to-face discrete method was employed to simulate the contact between steel tube and concrete. The normal contact was simulated as hard contact, and the tangential bond and slip were modeled with the Kulun friction model whose friction coefficient was set to 0.35 .

Our purpose is to acquire the SCF of CFST joints under the normal working condition, rather than the bearing capacity of these joints. Thus, the monotonic constitutive relation of concrete is not considered here. The elastic modulus was set to $\mathrm{E}=2.05 \times 105 \mathrm{MPa}$ (steel tube) and $3.45 \times 104 \mathrm{MPa}$ (concrete), and the Poisson's ratio was set to $\nu=0.3$ (steel tube) and 0.2 (concrete).

To disclose of the effect of the weld size, the two ends of all models were constrained by the same hinged connection; the steel grade was set to Q345; the strength of the filled concrete was set to C50; the friction properties were the same between steel tube and concrete.

For accuracy and efficiency, the grid size of finite-element modeling was determined in light of the previous studies (Fig. 6). The braces of all models were subjected to axial tension and in-plane bending moment (Figs. 7 and 8). The joints were in elastic phase throughout the simulation according to the rule of fatigue failure. 


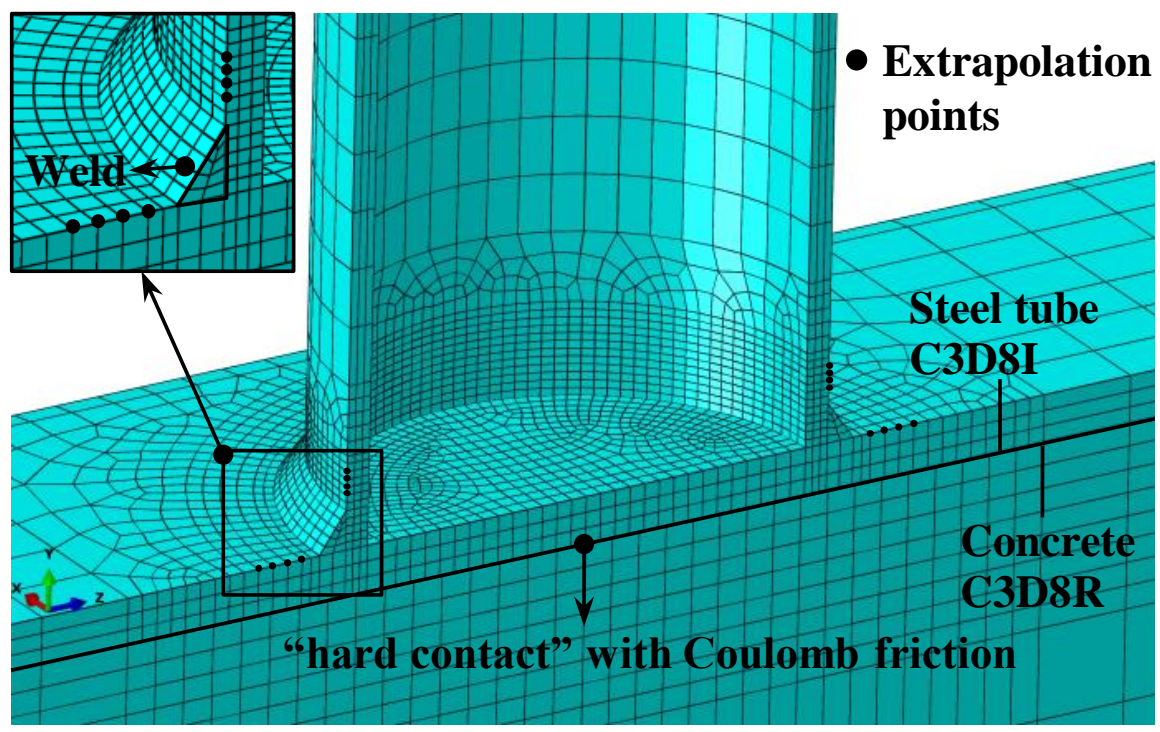

Figure 6: Finite-element grids of a CHS-CFSHS T-joint (partial).

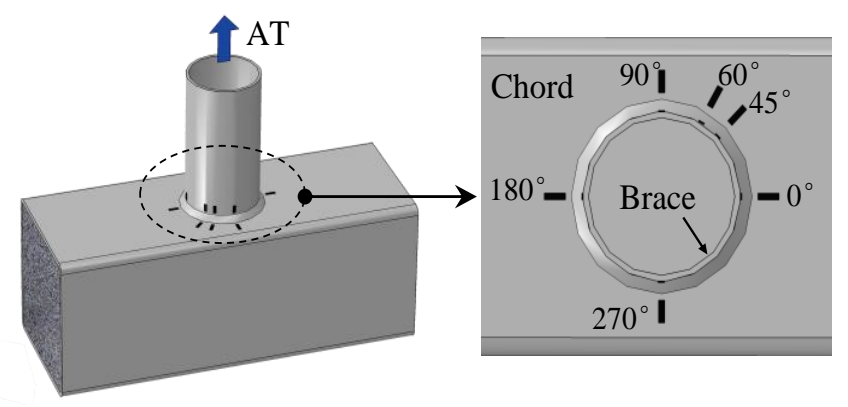

Figure 7: Condition of Axial Tension.
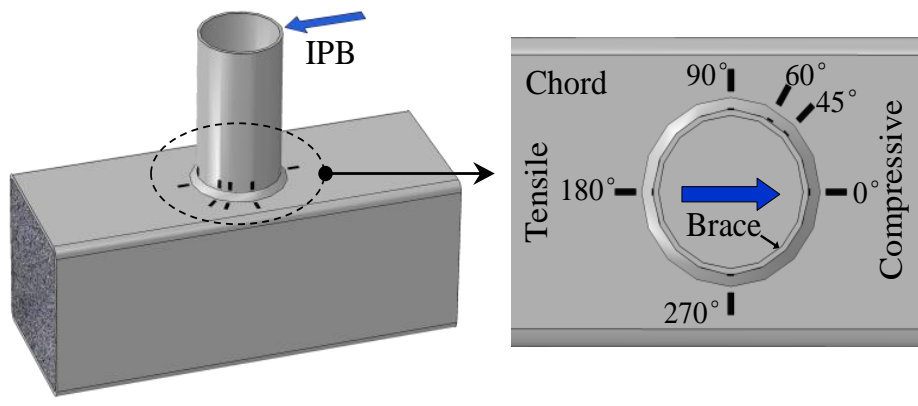

Figure 8: Condition of In-plane bending moment.

\section{Results and analysis}

Tabs. 1 and 2 show the SFC results in Conditions 1 and 2 respectively, According to the SCF calculation method in the existing achievements $[16,21]$. The following conclusions were drawn from the SCF results.

\begin{tabular}{|c|c|c|c|c|c|c|c|c|}
\hline \multirow{2}{*}{ Joints } & \multirow{2}{*}{$\mathrm{w} 0 / \mathrm{t} 1$} & \multirow{2}{*}{$\mathrm{w} 1 / \mathrm{t} 1$} & \multicolumn{3}{|c|}{ Brace-side SCF } & \multicolumn{3}{|c|}{ Chord-side SCF } \\
\hline & & & $0^{\circ}$ & $60^{\circ}$ & $90^{\circ}$ & $0^{\circ}$ & $60^{\circ}$ & $90^{\circ}$ \\
\hline $\mathrm{WT}_{1}$ & 0.5 & 1.2 & 3.61 & 5.82 & 6.70 & 5.48 & 7.96 & 9.05 \\
\hline $\mathrm{WT}_{2}$ & 0.5 & 2.0 & 1.70 & 3.82 & 4.48 & 5.60 & 8.34 & 9.29 \\
\hline $\mathrm{WT}_{3}$ & 1.2 & 1.2 & 4.19 & 6.66 & 7.56 & 5.06 & 7.06 & 7.76 \\
\hline $\mathrm{WT}_{4}$ & 1.8 & 1.8 & 3.29 & 5.76 & 6.63 & 4.87 & 6.46 & 6.95 \\
\hline $\mathrm{W}^{\prime} \mathrm{T}_{5}$ & 0.5 & 1.8 & 2.14 & 4.20 & 4.88 & 5.71 & 8.27 & 8.93 \\
\hline $\mathrm{WT}_{6}$ & 1.0 & 1.8 & 2.83 & 5.25 & 6.03 & 5.34 & 7.61 & 8.41 \\
\hline
\end{tabular}

Table 1: SCF in Condition 1. 


\begin{tabular}{lccccccc}
\hline \multirow{2}{*}{ Joints } & w0/t1 & w1/t1 & \multicolumn{3}{c}{ Brace-side SCF } & \multicolumn{3}{c}{ Chord-side SCF } \\
& & & $0^{\circ}$ & $135^{\circ}$ & $180^{\circ}$ & $135^{\circ}$ & $180^{\circ}$ \\
$\mathrm{WT}_{1}$ & 0.5 & 1.2 & 2.19 & 1.75 & 1.82 & 2.54 & 2.68 \\
$\mathrm{WT}_{2}$ & 0.5 & 2.0 & 1.78 & 1.23 & 1.18 & 2.59 & 2.72 \\
$\mathrm{WT}_{3}$ & 1.2 & 1.2 & 2.35 & 1.96 & 2.05 & 2.27 & 2.35 \\
$\mathrm{WT}_{4}$ & 1.8 & 1.8 & 2.25 & 1.77 & 1.83 & 2.08 & 2.11 \\
$\mathrm{WT}_{5}$ & 0.5 & 1.8 & 1.88 & 1.34 & 1.33 & 2.60 & 2.83 \\
$\mathrm{WT}_{6}$ & 1.0 & 1.8 & 2.13 & 1.63 & 1.64 & 2.41 & 2.47 \\
\hline
\end{tabular}

Table 2: SCF in Condition 2.

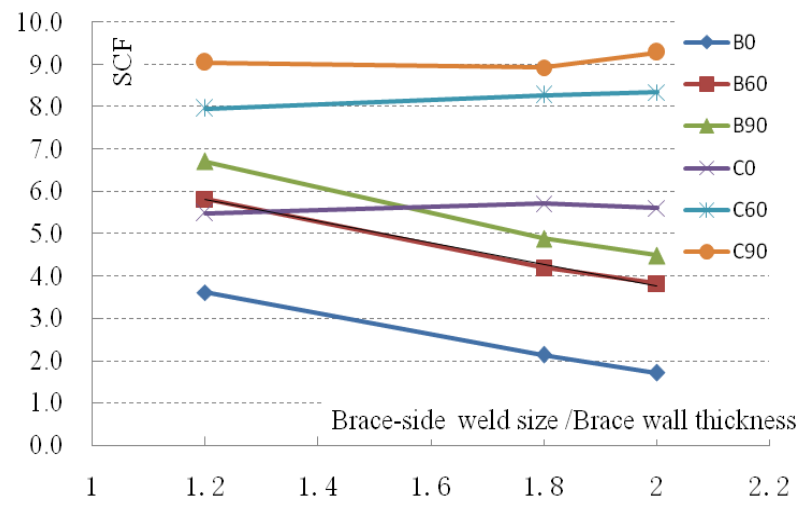

(a) effect of only size change of brace-side weld.

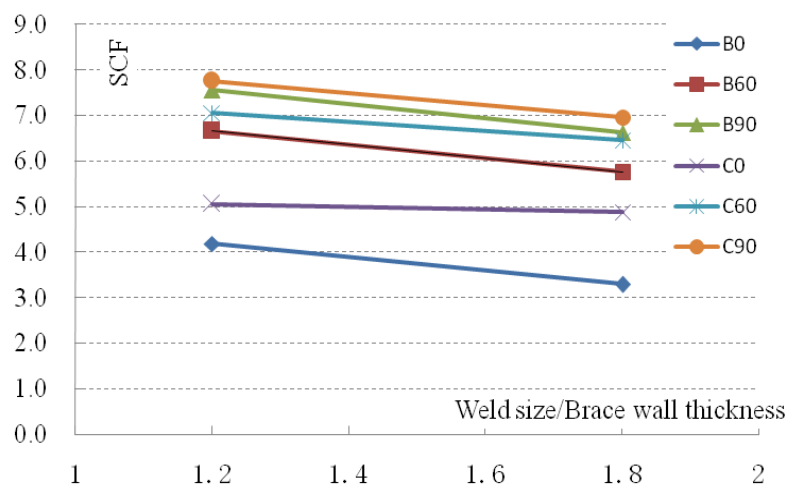

(b) effect of equal proportionally change of weld size

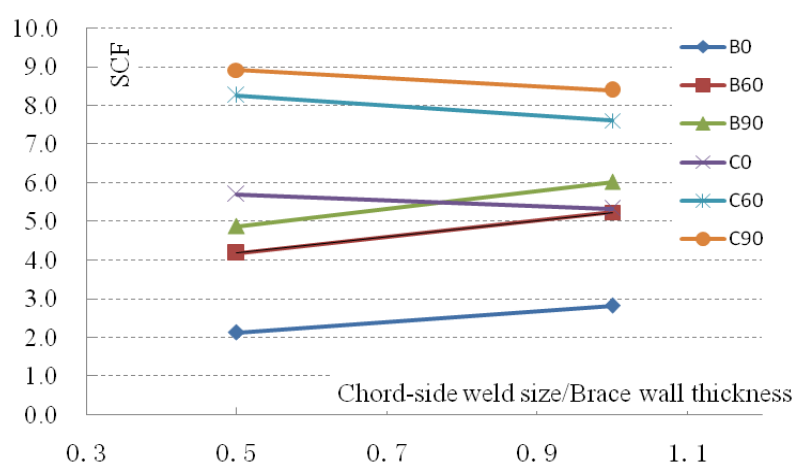

(c) effect of only size change of chord-side weld

Figure. 9: Effects of weld size on the SCF.

First, the weld size directly affected the hot spot stress in both conditions, and the influence laws were largely the same.

Second, the chord-side weld size was all $0.5 \mathrm{t} 1$, while the brace-side weld size was 1.2t1, 1.8t1 and 2.0t1, respectively, in WT1, WT5 and W'T2. In both conditions, the brace-side SCF plunged with the increase of brace-side weld size, while the chord-side SCF changed slightly less than 5\%. Fig. 9(a) illustrates the effect of weld size on the SCF in Condition 1. The effect of weld size in Condition 2 was similar to that in Condition 1. This is because the increase in brace-side weld size pushed the brace-side extrapolation region away from the stress hotspot, leading to reduced hot spot stress obtained by extrapolation.

Third, the weld size in WT3 was 1.2t1 at both brace-side and chord-side, and that in WT4 was 1.8t1 at both brace-side and chord-side. In both conditions, the SCF in WT3 surpassed that in WT4 at both brace-side and chord-side. Fig. 9(b) depicts the effect of fillet weld size on the SCF in Condition 1. The effect of fillet weld size in Condition 2 was similar to 
that in Condition 1. The results demonstrate that the brace-side and chord-side SCFs declined when the brace-side and chord-side weld sizes increased by the same amount.

Fourth, WT5 and WT6 shared the same weld size at the brace-side, but WT5 had half the weld size of WT6 at the chordsize. In both conditions, the SCF decreased slightly with the increase of weld size at the chord-size, and increased at the brace-side. Fig. 9(c) describes the effect of fillet weld size on the SCF in Condition 1. The effect of fillet weld size in Condition 2 was similar to that in Condition 1. The effects can be explained as follows: With the growth in chord-side weld size, the angle between weld surface and brace wall expanded, adding to the slope of the transition area between the weld and the wall.

\section{RECOMMENDED WELD SIZES}

Whrough the simulation of six models, it is clear that the joint SCF is indeed affected by weld size. This section attempts to recommend rational weld sizes for engineering practice. The idea of Wingerde fails to ensure the safety of brace-side SCF for full penetration butt weld, while the idea of Zheng Hongzhi complicates the SCF calculation with the consideration of brace-side minimize weld size. Considering the relevant specifications, the author recommended the following weld sizes which are easy to compute and implement.

First, the chord-side SCF of full or partial penetration weld joints increased significantly with the decrease of chord-side weld size, but insensitive to the variations in brace-side weld size. In actual projects, the weld size should be minimized at chord-side and set to a common size at brace-side (Fig. 10(a)). The chord-side SCF calculated of our finite-element model is the upper limit of the actual chord-side joint SCF. Thus, it is safe for engineering application.

Second, the brace-side SCF of full or partial penetration weld joints was almost the same as that at chord-side, because the joint SCF increased with the decrease of weld size. Thus, both brace-side and chord-side weld sizes were 1.2t1 (Fig. 10(b)). The brace-side SCF calculated of our finite-element model is the upper limit of the actual brace-side joint SCF. Thus, it is safe for engineering application.

Third, the fillet weld size was set to 1.2t1 for simplicity and applicability, because the SCF of fillet weld joints grew with the decrease of weld size. The size was the same as that for computing the brace-side SCF of joints connected by full or partial penetration weld (Fig. 10 (c)). The SCF calculated from our finite-element model is the upper limit of the actual fillet weld joint SCF. Thus, it is safe for engineering application.

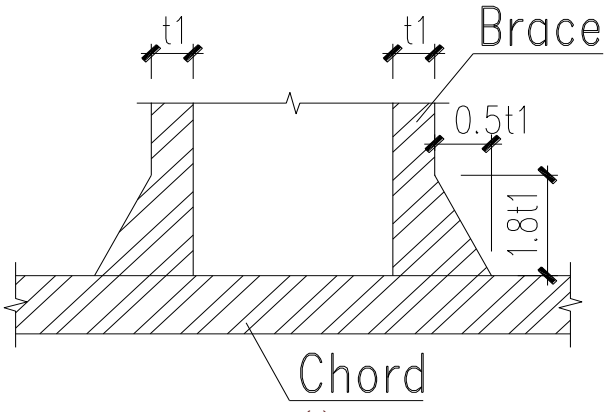

(a)

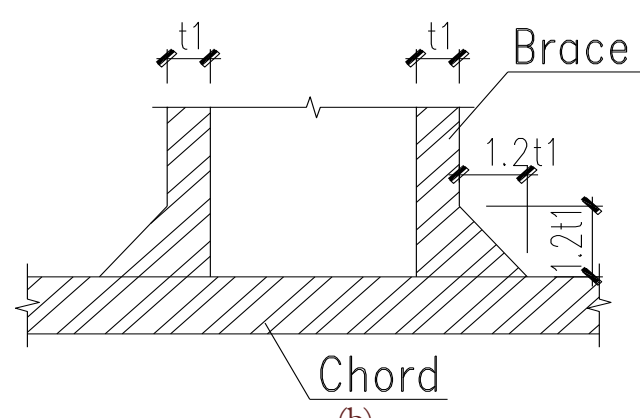

(b)

Figure 10: Recommended weld sizes in finite-element calculation.

\section{CONCLUSIONS}

$\mathrm{F}$ inite-element analysis reveals that the weld size directly affected the hot spot stress in both conditions, and the influence laws were largely the same. With the increase of weld size, the brace-side SCF plunged when the chordsize weld size remained the same, but the chord-side SCF changed slightly when the brace-side weld size was constant. Brace-side and chord-side SCF declined when the brace-side and chord-side weld sizes increased by the same amount. The recommended weld sizes are consistent with the relevant specifications and safe and simple to apply in actual engineering. 


\section{ACKNOWLEDGMENTS}

he authors wish to thank the Natural Science Foundation of China for financially supporting the research in the paper through the grant NO.51478334 and Henan Science and Technology Department supporting the research in the paper through the grant NO.122102210087 and NO.182102310918.

\section{REFERENCES}

[1] Han, L. H. and Yang, Y. F. (2007). Modern technology of concrete-filled steel tubular structures, 2nd ed. Beijing, PR China: China Architecture \& Building Press.

[2] Han, L. H., Li, W. and Bjorhovde, R. (2014). Developments and advanced applications of concrete-filled steel tubular (CFST) structures: Members, Journal of Constructional Steel Research, 100, pp. 211-228.

[3] Wingerde, A. M. V., Packer, J. A. and Wardenier, J. (1995). Criteria for the Fatigue Assessment of Hollow Structural Section Connections, Journal of Constructional Steel Research, 35, pp. 71-115.

[4] Recommended practice for fatigue strength analysis of offshore steel structures, DNV RP-C203, (2001).

[5] Zhao X. L., Herion, S. and Packer, J. A. (2001). Design Guide for Circular and Rectangular Hollow Section Welded Joints under Fatigue Loading, CIDECT and TUV-Verlag, German.

[6] Hobbacher, A. F. (2008). Recommendations for Fatigue Design of Welding Joints and Components, International Institute of Welding, doc. XIII-2151-07/XV-1254-07.

[7] AWS D1.1-2008. Structure Welding Code-Steel, the American National Standards Institute, American Welding Society, (2008).

[8] Packer, J. A., Mashiri, F. R., Zhao, X. L. and Willibald, S. (2007). Static and fatigue design of CHS-to-RHS welded connections using a branch conversion method, Journal of Constructional Steel Research, 63, pp. 82-95.

[9] Mashiri, F. R. and Zhao, X. L. (2010). Square hollow section (SHS) T-joints with concrete-filled chords subjected to in-plane fatigue loading in the brace, Thin-Walled Structures, 48, pp. 150-158.

[10] Mashiri, F. R., Zhao, X. L. and Tong, L. W. (2013). Fatigue tests and design of thin CHS-SHS T-joints under cyclic in-plane bending, J Civil Struct Health Monit., 3, pp. 129-140.

[11] Wang, K., Tong, L. W., Zhu, J., Zhao, X. L. and Mashiri, F. R. (2013). Fatigue Behavior of Welded T-Joints with a CHS Brace and CFCHS Chord under Axial Loading in the Brace, Journal of Bridge Engineering., 18, pp. 142-152.

[12] Kim, I. G., Chung, C. H., Shim, C. S. and Kim, Y. J. (2014). Stress concentration factors of N-joints of concrete-filled tubes subjected to axial loads, Int J Steel Struct., 14, pp. 1-11.

[13] Qian, X. D., Jitpairod, K., Marshall, P. and Swaddiwudhipong, S., Ou, Z. Y., Zhang, Y., Pradana, M. R. (2014). Fatigue and residual strength of concrete-filled tubular X-joints with full capacity welds, Journal of Constructional Steel Research, 100, pp. 21-35.

[14] Tong, L. W., Xu, G. W., Liu, Y. Q., Yan, D. Q. and Zhao, X. L. (2015). Finite element analysis and formulae for stress concentration factors of diamond bird-beak SHS T-joints, Thin-Walled Structures, 86, pp. 108-120.

[15] Tong, L. W., Xu, G. W., Yan, D. Q. and Zhao, X. L. (2016). Fatigue tests and design of diamond bird-beak SHS Tjoints under axial loading in brace, Journal of Constructional Steel Research, 118, pp. 49-59.

[16] Tong, L. W., Zheng, H. Z., Mashiri, F. R. and Zhao, X. L. (2013). Stress-Concentration Factors in Circular Hollow Section and Square Hollow Section T-Connections: Experiments, Finite-Element Analysis, and Formulas, Journal of Structural Engineering, 139, pp. 66-81.

[17] Technical Specification for Structures with Steel Hollow Sections (CECS 280:2010), Beijing, China; China Plan Press., (2010).

[18] Technical Specification for Welding of Steel Structure of Building (JGJ 81-2002), Beijing, China; China Construction Industry Press., (2002).

[19] Code for Design of Steel Structures (GB 50017-2013), Beijing, China; China Standard Press., (2010).

[20] SIMULIA. Abaqus 6.12. Analysis User's Manual, (2013).

[21] Tong, L. W., Yang, D. L. and Zhao, X. L. (2013). Experimental Study on Fatigue Behaviour of Welded CHS-toConcrete Filled SHS T-joints. Journal of Variation and Shock, 2, pp. 99-105. 